\title{
Primary Health Care in the rural context: the nurses' view
}

\author{
A Atenção Primária à Saúde no contexto rural: visão de enfermeiros \\ Atención Primaria de Salud en el contexto rural: la visión de la Enfermería
}

Arleusson Ricarte de Oliveira
Yanna Gomes de Sousa $^{\mathrm{b}}$
Doane Martins da Silva $^{\mathrm{c}}$
Jairo Porto Alves $^{\mathrm{d}}$
Ítalo Vinícius Albuquerque Diniz
Soraya Maria de Medeiros $^{\mathrm{d}}$
Claudia Santos Martiniano $^{\mathrm{f}}$
Marília Alves $^{\mathrm{d}}$

How to cite this article: Oliveira AR, Sousa YG, Silva DM, Alves JP, Diniz IVA, Medeiros SM, Martiniano CS, Alves M. Primary Health Care in the rural context: the nurses'view. Rev Gaúcha Enferm. 2020;41:e20190328. doi: https://doi.org/10.1590/19831447.2020.20190328 aniversidade Federal de Campina Grande (UFCG) Unidade Acadêmica de Enfermagem. Campina Grande, Paraíba, Brasil.

- Universidade Federal do Rio Grande do Norte(UFRN), Programa de Pós-Graduação em Enfermagem. Natal, Rio Grande do Norte, Brasil.

Universidade Federal de Minas Gerais (UFMG), Escola de Enfermagem, Departamento de Gestão em Saúde. Belo Horizonte, Minas Gerais, Brasil.

¿ Universidade Estadual da Paraíba (UEPB), Programa de Pós-Graduação em Saúde Pública. Campina Grande, Paraíba, Brasil.

Universidade Federal do Rio Grande do Norte (UFRN) Programa de Pós-Graduação em Enfermagem, Departamento de Enfermagem. Natal, Rio Grande do Norte, Brasil.

† Universidade Estadual da Paraíba (UEPB), Programa de Pós-Graduação em Saúde Pública, Departamento de Enfermagem. Campina Grande, Paraíba, Brasil.

- Universidade Federal de Minas Gerais (UFMG) Escola de Enfermagem, Programa de Pós-Graduação em Enfermagem. Belo Horizonte, Minas Gerais, Brasil.

\section{ABSTRACT}

Objective: To analyze the view of nurses from the Family Health Strategy on the health care of rural populations.

Method: A qualitative and exploratory research conducted with eleven nurses working in rural areas, conducted from January to March 2017, in Campina Grande-PB. Data was collected through semi-structured interviews and analyzed by the Content Analysis technique.

Results: Nurses associate the health context of the rural population with the living conditions of the community, with the lack of access to health services, and with the peculiarities of work resulting from this context. The satisfaction of rural PHC nurses is associated with professional identification and bond with the population.

Conclusions: Nurses perceive the particularities that involve the rural context requiring differentiated health care that positively impacts their work.

Keywords: Nursing. Primary health care. Rural health.

\section{RESUMO}

Objetivo: Analisar a visão de enfermeiros da Estratégia de Saúde da Família sobre a atenção a saúde de populações rurais.

Método: Pesquisa qualitativa, exploratória realizada com onze enfermeiros que atuam em área rural, realizada de janeiro a março de 2017, em Campina Grande-PB. Os dados foram coletados por meio de entrevistas semiestruturadas e analisados pela técnica de Análise de Conteúdo.

Resultados: Os enfermeiros associam o contexto de saúde da população rural às condições de vida da comunidade, à escassez de acesso aos serviços de saúde e às peculiaridades de trabalho decorrentes desse contexto. A satisfação do enfermeiro da APS rural associa-se à identificação com o contexto da saúde no meio rural e vínculo com a população.

Conclusões: Os enfermeiros percebem a dinâmica de trabalho particular que envolve o contexto rural necessitando de atenção à saúde diferenciada que impacte de forma positiva em seu trabalho.

Palavras-chave: Enfermagem. Atenção primária à saúde. Saúde da população rural.

\section{RESUMEN}

Objetivo: Analizar la opinión de los enfermeros del programa Estrategia de Salud de la Familia sobre la atención de la salud de las poblaciones rurales.

Método: Investigación exploratoria y cualitativa realizada con once enfermeros que trabajan en áreas rurales, realizada de enero a marzo de 2017, en Campina Grande-PB. Los datos se recolectaron por medio de entrevistas semiestructuradas y el análisis de datos se llevó a cabo por la técnica de Análisis de Contenido.

Resultados: Los enfermeros asocian el contexto de salud de la población rural con las condiciones de vida de la comunidad, la falta de acceso a los servicios de salud y las peculiaridades del trabajo derivadas de este contexto. El grado de satisfacción de los enfermeros rurales de la APS está asociado con la identificación profesional y el vínculo con la población.

Conclusiones: Los enfermeros advierten las particularidades inherentes al contexto rural que requiere de una atención médica diferenciada capaz de ejercer un efecto positivo en su trabajo.

Palabras clave: Enfermería. Atención primaria de salud. Salud rural. 


\section{口INTRODUCTION}

The Brazilian Unified Health System (Sistema Único de Saúde, SUS) proposes to guarantee the population the right to health by expanding the coverage, access and comprehensive care, considering the different needs of different population groups in order to reduce health inequities ${ }^{(1)}$. However, despite advances in expanding access to the care services, people living in the rural environment still face difficulties in accessing resolutive health services, especially when they are under complex health conditions.

Health care for rural populations is a complex demand and a worldwide concern, since there are difficulties in establishing professionals in practice for long periods in rural areas due to the lack of an "improved retention" program addressing factors that influence the decisions of the health workers to remain in these areas, as well as health system policies and interventions that respond to these factors; the population is dispersed in difficult access areas ${ }^{(2)}$; living and working conditions differ from urban situations due to precariousness, and the most advanced technologies are concentrated in large urban centers, among other situations, which make it difficult for users to refer to specialized treatments ${ }^{(3)}$.

In relation to the Primary Health Care (PHC), referred to as Basic Care (BC) in Brazil, the National Basic Care Policy (Política Nacional de Atenção Básica, PNAB) has the Family Health Strategy as a priority for BC expansion and consolidation. This strategy is operationalized through the following principles: Universality; Equity; and Integrality. Its guidelines are the following: Regionalization and Hierarchization, Territorialization, Enrolled Population, Person-centered care, Resolutivity, Longitudinality of care, Coordination of care, Network ordering, and Community participation ${ }^{(1)}$. However, little is known about the effectiveness of the interventions and their sustainability in rural areas.

Although there is, in Brazil, a National Policy for Comprehensive Health for Rural and Forest Populations, in the practice, it is possible that this policy is not articulated with the country's National PHC Policy. Currently, the policy that regulates PHC in Brazil is Ordinance GM 2436/2017(1), which applies to both urban and rural areas.

It is noteworthy that the World Health Organization (WHO) estimates that $50 \%$ of the world population live in rural and remote areas and is served by $38 \%$ of the nursing workforce and less than $25 \%$ of the medical workforce. The poor spatial distribution of the health workforce represents an obstacle to achieving universal health coverage and is a reason for concerns about equity, since it affects access to care for those who have allocation efficiency, as the resources are not properly invested in areas where they would have the major impact(4).

In addition to the geographical dimension, other challenges hinder the development of the health system in Brazil, including social and economic, cultural, educational, and structural inequalities, which favors high rates of poverty and illiteracy, sanitation and insufficient access to health services at all their levels $s^{(5)}$. Regarding mortality in the urban and rural areas, the group of children under 1 year old concentrates $3.1 \%$ of the total deaths, while in the rural area, this percentage is $5.4 \%$. The biggest difference was found in the group going from 1 to 4 years old, where the percentage of the rural area was $1.6 \%$, which is more than twice as in the urban area $(0.7 \%)^{(6)}$.

The rural population also faces the lack of regular access to drinking water sources, it is estimated that $72.2 \%$ of the Brazilian rural population access water through wells, puddles, dams and muds, and this precarious access has great potential to provoke infectious gastroenteritis and their complications ${ }^{(6)}$. A study that evaluated the frequency of Hospitalizations for Sensitive Conditions in the Primary Care between 2004 and 2015 showed that in small municipalities with a large proportion of rural population (79\% to 51\%), infectious gastroenteritis and their complications were the main causes of hospitalization ${ }^{(7)}$.

Despite the wide coverage of PHC in Brazil, with more than half of the population assisted by the FHS teams, there are still differences regarding access to and the provision of health care for rural populations in which the FHS has the challenge of facing the guarantee of comprehensive care. A study ${ }^{(8)}$ found that inequalities in access to primary health care in rural areas are even greater, due to the lack of drugs and tests, the limitations on users' return to other services and the lack of health professionals in some remote areas. In this regard, it is highlighted that in Latin America the deficit of physicians and, above all, nurses is high, with an inadequate professionals' distribution. Urban areas concentrate more of these professionals than in rural and remote areas ${ }^{(9)}$.

Regarding the allocation of personnel in rural areas at the international level, the $\mathrm{WHO}^{(10)}$ recommends some adherence strategies for health workers to work in rural areas, in order to contribute to the implementation of health actions to improve people's quality of life: the insertion of future professionals during undergraduate course in the rural community experiences; the provision of scholarships or other educational grants with return of service provision in rural or remote areas, and for workers already inserted in the rural area, the implementation of a permanent education program in rural health. 
With regard to the work of health professionals in rural areas, it is common to occur in situations of relative isolation or with a smaller number of professionals and few resources, despite the existence of a close relationship between health professionals and rural communities ${ }^{(11)}$. In relation to the daily work of nurses in rural areas of the PHC, there is a different work dynamic, conditioned by the characteristics of rural life, and by the difficulties inherent to the life and health conditions of the population that demands health care. Thus, the choice of nurses as participants in the study was due to the relevance of these professionals in $\mathrm{PHC}$, involvement with the teamwork that in the FHS develop activities of an educational, assistance and administrative nature, including coordination activities for nursing and CHA team.

Given the above, the following question arose: What is the nurses' view on the care provided to the health of rural populations monitored in Primary Health Care? Given the questions, this study may contribute to the reflections about the work of nurses in the context of the rural PHC, which has not yet been studied, as well as enabling the production of knowledge about work in reality in a contextualized way, since the global challenge is to reach the universal access and coverage to health, guaranteeing nurses a high performance potential to contribute to the advancement of the PHC, especially in rural populations. Thus, the study aimed to analyze the vision of nurses of the Family Health Strategy on the health care of rural populations.

\section{METHOD}

An exploratory-descriptive study of a qualitative nature, carried out with all the teams of the Family Health Strategy in a rural area in the municipality of Campina Grande-PB. Initially, prior contact was made with the Municipal Health Secretariat by telephone with the Coordinators of the Health Districts in order to explain the purpose of the research and to request an appointment to start the interviews with the nurses.

The research participants were 11 nurses who corresponded to the following inclusion criteria: being a nurse at the FHS of Campina Grande-PB, working in an exclusively rural area for at least 06 (six) months, guaranteeing experience in this area, and belonging to the staff of permanent or contracted professionals in the municipality. There was no exclusion criterion.

Data collection took place from January to March 2017, through individual interviews, using a semi-structured script. The questions that made up the roadmap were developed by the researchers based on the scientific literature and through inquiries related to the work of nurses in the rural area. The questions involved aspects of the nurses' daily work. The interviews were carried out using an MP4 recorder, by the researcher themselves in a reserved place of the $\mathrm{FHU}$, in the morning and evening periods according to the schedule.

The interviews were fully recorded and transcribed and lasted from 30 to 40 minutes. After the end of the interviews, the participating professional was asked whether they would like to hear the recording. Each interview was identified by the letter E - (for interviewee, "entrevistado" in Portuguese), followed by a number in sequential order (E1, E2, E3, E4, successively up to E11). They were later transcribed and made available to the participants for reading, in order for them to judge the veracity of the information.

For data analysis, Content Analysisis ${ }^{(12)}$ following its three stages was used: pre-analysis, in which the testimonies' floating reading was carried out; followed by an exhaustive reading of the material when the recording units were selected, forming a clipping of the reports for later organization. In the third stage, the registration units were organized into categories and interpreted according to the literature. The results were organized into four categories: Living conditions in rural areas: Place of needy population; The Family Health Unit as the only alternative to access health care for the rural population; The work dynamics imposed by the peculiarities of the rural context and the (Im)possibility for guaranteeing comprehensive care; The satisfaction of rural PHC nurses: identification with the context of health in the rural environment, learning and growth, and the link with the population.

The participants signed the Free and Informed Consent Form in compliance with the determinations contained in resolution 466/12 of the National Health Council, and the research was approved by the Research Ethics Committee of the Federal University of Minas Gerais, under CAE No. 62508016.1.0000.5149.

\section{RESULTS}

The research was carried out in the municipality of Campina Grande-PB, one of the largest cities in the inland of Northeast Brazil, with an urban population of 367,209 inhabitants and a rural population of $18,000^{(13)}$. It has three rural districts, with 11 Family Health teams, located in the west, northwest and east, with a distance between 12 and $26 \mathrm{~km}$ from the city center.

Of the eleven nurses interviewed from family health teams in rural areas of the studied city, in relation to the age group, there was a predominance of the individuals between 30 and 50 years old (90\%), most of them female (91\%). The time of work in the FHS in the rural area ranged from one 
to six years (36\%) and from seven to twelve years (45\%). Regarding the work regime, $82 \%$ were statutory.

\section{Category 1: Living conditions in rural areas: Place of needy population}

The category reveals that the rural population assisted by nurses from family health teams has as the financial resources derived from activities related to agriculture and/or retirement its source of income. There is also a high number of unemployed people, with a low level of education, and many are beneficiaries of social programs of the federal government, such as the Bolsa Família Program.

We work with poor people, mainly in settled areas, they are in need of clarification, with a very low educational level (E-7).

Most live on the Bolsa Familia and sometimes on rural retirement, do you understand? There are people who live in the mountains, then they go to our unit which is far away, they come on foot, sometimes they come by motorcycle, those who have a motorcycle, those who don't have it come on foot. Those who come in the morning come with the sun down and to return is terrible, no one who can take that heat (E-8).

The testimonies show the unfavorable living conditions of the rural population and the difficulties in accessing the health services, revealing that, although there are health services available, the population faces adverse conditions to seek them.

\section{Category 2: The Family Health Unit as the only alternative to access health care for the rural population}

This category reveals that the Family Health Unit (FHU) is the only health service that the population seeks in case of need. Unlike urban units, rural units are not open every day of the week, as the health team has a peculiar work schedule and moves weekly to several units that are distributed in different places in the rural territory.

[...] You often refer a pregnant woman to the referral hospital in the city, for example, and they will not go... Due to financial difficulties, transport difficulties. (...) and those who work in the countryside have difficulties even with basic things like transportation, taking a blood test because the person is unable to pay for the car to go... [...] (E-6).
[...] as a Family Health team, I believe that we contribute to the improvement of the health and disease process in the rural community, however there are many situations in which we have to "get by" in order to solve the problems. We don't have NASF here... [...] I think that the public health system by itself was conceived within a vision of the city, you know, I think that, in general, even from the Ministry, they thought about the city. So they didn't think about the specifics of the rural area [...]. (E-8).

These testimonies reveal the isolation of the rural teams in health care in their territory and the difficulty of establishing a flow within the care network. This is because, in the daily work, the nurse and the entire team in the rural area also face difficulties in the absence of matrix support provided by the team from the Extended Center for Family Health and Basic Care (Núcleo Ampliado de Saúde da Família e Atenção Básica, NASF-AB)', being important with regard to the assistance in resolving health problems present in the territory that depend on an expanded clinic $^{2}$, as well as the implementation of other Ministry of Health's programs that contribute to improving the quality of life for the rural population.

\section{Category 3: The peculiarities of the rural context and the organization of nursing care in the logic of teamwork in Primary Health Care}

Regarding work in rural areas, nurses deal with a unique work schedule, in view of the specific characteristics present in the configuration of the territory, where the population is dispersed. Another aspect is that the geographical distance of the rural area in relation to the city (between 12 and $26 \mathrm{~km}$ ) influences the development of comprehensive care for nurses, who need the intermediation of management to coordinate care.

\footnotetext{
1 The NASF-AB was configured as a multidisciplinary team that should act in an integrated manner with the Family Health Strategy (FHS) teams, allowing for the discussion of clinical cases; shared care among professionals, and enabling the joint construction of therapeutic projects in order to expand and qualify interventions in the territory and in the health of population groups. However, Technical Note No. 03/2020 revoked the ordinance that created it, leaving the local manager the responsibility to define new arrangements for multi-professional teams.

${ }^{2}$ The expanded clinic is a guideline of the National Humanization Policy and consists of a theoretical and practical tool with the purpose of contributing to a clinical approach to illness and suffering, considering the uniqueness of the subject and the complexity of the health/disease process, allowing to face the fragmentation of knowledge and of the health actions in searching for a balance between the harms and benefits generated by the health practices.
} 
[...] A difference factor among the urban and rural services is the team's internal work. In the urban area it is easier to make a schedule, divide the time for pregnant women, children, hypertensive patients, women's health... In the countryside, as we only go once a week to each location, we end up taking care of everything together... [...] It would be interesting that the service here was the two shifts, we have regular hours here (E-7).

We work with a schedule, you know, a schedule of monthly activities, then they already know what the service will be, both mine and the doctor's and then the CHA already goes through the community, warning, and people come (E-8).

If I stayed in one place all the time, for example, if I stayed two days in each place, I would do a better job because I would have time to talk (E-10).

As the rural area is far away from the city center, and it is far from the media, and because it is far away from all this, so, like this, it is kind of hidden, so that the management is not as concerned as those of the urban area where it is more visible by the population. So, then, I do not know if for this reason that health units in rural areas suffer from this precariousness of both material and physical structure. I feel unassisted by the management (E-4).

\section{Category 4: The satisfaction of the rural PHC nurse: Identification with the health context in the rural environment}

In the work of the FHS in rural areas, nurses find a source of appreciation and identification with the health context in the rural environment. The statements show that they recognize themselves in the profession in addition to considering themselves as active subjects in professional practice, and this makes them feel pleasure and satisfaction, giving positive meaning to what they do.

I find it pleasant to work in a rural area. I once heard a phrase, in fact I never forgot it: "do what you like and you will never need to work." And really for me I would stay here until five, six o'clock in the afternoon and I wouldn't mind (E-2).

When I chose nursing, I did it because I like the health area and because I really wanted to be a nurse [...] the little I do I do it with pleasure [...] / feel very valued working in the rural area. If you ask, do you want to move from this FHP to an urban area? I say no, leave me here as I am until I retire (E-3).
The statements also reveal that, although the work of the FHS nurse in the countryside is permeated by daily challenges, there is also space for learning and growth with the experience at work, in addition to the bond established with the population.

With the family health, Ilearned to be more human, to listen more and not to speak more, because I was quite a chatterbox, you know, we arrive with that thing of the university that has a lot of information to pass on, more to listen to, to become more human, even less arrogant with the way of talking to people, this was shaping me with everyday life ( $\mathrm{E}-1)$.

[...] I even think that as a professional, I think I improved a lot... according to this reality that I found... I learn a lot here with them, with these people, according to when I listen to their reality. (E-11).

My work is gratifying, I really like what I do. Today I don't see myself in the hospital. The bond we have with people. We already know almost all the people by their names, I call them by their names. Then this is another attraction for them related to us, right, because they feel well liked, right... (E-5).

\section{DISCUSSION}

The results pointed to the dominance of situations present in the nurses' daily work that influence the quality of care provided to people living in the rural area. However, in the context of rural FHS, the characteristics of the work make it difficult to implement changes in health care practices and, consequently, to achieve comprehensive care.

In the rural community under study, the striking particularities that nurses attribute to the population's living conditions are expressed through specificities of the rural environment, in view of the obstacles of geographical, economic, cultural accessibility, and information barriers. These obstacles are aggravating factors that worsen the life situation in the rural setting, as they impact the production and consumption necessary for sustenance, also interfering in the health-disease process and in their quality of life. The cultural issue in the rural area has great relevance, and this can cause difficulties for the development of health actions that permeate the daily work of the teams working in this scenario, as some customs compete with the prescriptions contained in singular therapeutic projects. Thus, the health workers working in PHC need to implement strategies that take into account the understanding of how individuals 
think and act in the face of their problems and health care in favor of quality of life ${ }^{(13)}$. The Family Health Strategy professionals who work in rural areas face several challenges to fully perform their duties. In this environment, it is essential to know its particularities so that the appropriate conditions are developed for the understanding of the information to be disseminated and to provide changes, considering the specificities of the environment and the different possibilities for carrying out the health team work ${ }^{(11)}$. Basic Care considers the person in their uniqueness and socio-cultural insertion, seeking to produce comprehensive care, incorporating health surveillance actions for the protection of the population's health, the prevention and control of risks, diseases and illnesses, as well as for health promotion ${ }^{(1)}$.

This study reveals that the FHU is sometimes the only health care alternative for the people who live in a rural setting, and a slightly more serious situation is the isolation of this service within the assistance network. The rural area has several challenges and obstacles that end up hampering access to information for the population, among them: the time elapsed between consultations with the health team and the lack of efficient transportation between the community and the reference places for them to access diagnostic health resources. It should be noted that one of the responsibilities common to all spheres of government, described in the current National Basic Care Policy is to guarantee the population universal, equitable, and orderly access to the SUS health actions and services ${ }^{(1)}$.

It is evident that access is the result of both the combination of human and physical resources available and of the administrative and financial systems that determine which individuals will receive the services that the resources allow offering and under what conditions, taking into account some factors of globality such as the difficulties imposed by specialization in some areas, the criteria for access and entry, the allocation of labor, remotely, opening hours and quality of care ${ }^{(14)}$.

The study ${ }^{(15)}$ that analyzed the factors which influence access to the health services in the view of professionals and users found the existence of three access dimensions: Structural (financing) in which underfunding the health system constitutes a difficulty in accessing the health services; Relational (understanding of the health-disease process) where the lack of alignment on the structure and functioning flows of the health system negatively impact the professional's relationship with the user; and Operational (organization of services) which hinders access and the operational dimension, in which health professionals and users reported important gaps such as FHS coverage, scheduling appointments, welcoming, geographical barriers, reference and counter-reference.

In relation to the work dynamics imposed by the peculiarities of the rural context, it was highlighted that the health actions implemented are almost entirely mediated by spontaneous demands, with no time to idealize and execute activities according to a programmed demand. The periodicity of the nurse's work days in the area covered by the FHU ends up influencing the quality of care provided, as nurses have reduced work shifts in each FHU given the territorial location of each one. On the other hand, in urban areas, the population covered by the FHU is closer and the nurse tends to have more work shifts accompanying the same population. The nurse's greater contact with the residents favors the continuity of care and the longitudinality of care improving care quality for the people $e^{(16)}$.

In this sense, taking into account the reduction of shifts of care by rural community, it is emphasized that in this context there is a predominance of assistance centered on medicalization and cure, with low resolution and precarious social impact, in view of the absence of activities that privilege the empowerment of the community with regard to health care with a view to promoting a healthy life.

It reinforces the idea of a constant search by the nurse for improving the rural health associated with the attributes of Primary Health Care (PHC) with the orientation towards the real needs of communities with the adoption of evidence-based solutions to be put into practice. It is necessary to emphasize that the nurse who works in PHC has the possibility to systematize a praxis in the perspective of the integral care of families and communities throughout their life cycle, thus contributing to the consolidation of changes in the SUS healthcare-related mode|(17). Integrality in the SUS is based on the concept that the population should be cared for according to their needs and that health institutions should be structured in order to guarantee comprehensive health care.

The analysis of the testimonies showed that the nurses in this study are satisfied with the work in the rural area FHS, reflected, especially in the identification with the context of health in the rural setting, in the growth and learning provided with the work, and in the bond established with the population.

In this study, the testimonies of the nurses that relate to growth and learning with work concern the experiences acquired by the nurses through the work developed, as well as the possibility of, in working with rural families who are in unfavorable conditions, becoming more solidary and thus contribute to people's health, aspects that are fundamental 
to intensify the relationship with the community. Due to the fact that nurses live with the rural population and getting to know the needs of this collective, which are reflected above all by the deficit of adequate socioeconomic conditions, is a reason for satisfaction for this professional to be able to provide answers to the health needs of the population cared for.

One of the major challenges for Nursing is to combine its practice with those of the individuals to be cared for, seeking ways of caring in the otherness. It is necessary for health professionals to consider the social context that permeates the relationships and interrelationships of individuals, to meet the needs of the rural family ${ }^{(18)}$. In addition, the formation of the NBCP, which was followed by the current PHC financing policy, constitutes a macro challenge to the performance of health professionals, since it attacks the principles of the SUS, such as universality and equity. Establishing the registration of 4,000 people as a financing criterion makes it difficult to build and maintain the link with the users.

It is important to highlight that the bond portrays a connection between the concepts of accountability, humanization and integrality: in addition, it favors the acquisition of knowledge about the living conditions of the families monitored in the FHUs and facilitates the development of an expanded understanding regarding the health-disease process $^{(19)}$. A study ${ }^{(20)}$ that evaluated the establishment of a professional-user bond found that it is necessary for the professionals to strip off (pre)concepts and vertical discourses, in order to insert themselves into the community, such as knowing the reality of the families.

Considering the job satisfaction of nurses in the scope of the rural FHU, it is emphasized that the pleasure present in the care relationship at work facilitates the meeting between the health worker and the user, which allows for the creation of an intercessor space in this process, in which there is a mutual relationship of intervention in action, then a relationship of affection, trust, and responsibility arises. Thus, job satisfaction is able to contribute to the development of a set of favorable feelings, which contribute to the professional's commitment to providing qualified care, which can reflect in improving the quality of health service actions ${ }^{(17)}$.

This study has the limitation of having been carried out in a specific rural area, and its generalization is not possible, given the diversity of rural life in Brazil.

\section{$\square$ CONCLUSIONS}

Nurses perceive the rural population as being unfavored in resources and access to health services, due to the specific characteristics of their life context and the conditions imposed by the rural setting on these inhabitants.
The context of life and health of the rural population imposes on nurses the need for professional improvement to working in specific PHC areas in order to expand the health care of the population with an emphasis on comprehensive care.

This study reveals the importance of educational institutions in the training of nurses to include in their course plans content which addresses rural specificities and which influences the modus operandi of the professionals working in rural areas.

Despite the challenges imposed by the nurse's work in rural areas, there is satisfaction on the part of the professional to be working with this population, reflected in the identification with the context of health in the rural environment and in the bond established with the population, in addition to the learning and growth acquired with the work in this context, which requires specific professional profiles, strategies and skills for job performance.

The challenge includes achieving universal access to health care with the guarantee of nurses with high potential for job performance. As a possibility, there is a worldwide trend for advanced practice nurses with training and regulation to contribute to PHC advancement to work in the care services, especially with rural populations and in social inequality situations, in view of the population's high need for health and the lack of access to trained professionals with adequate distribution, to act in health promotion, disease prevention, and maintenance of people's health.

It is necessary to involve the set of social actors, including the population, professionals, and managers, to discuss health care in the rural context as a way of guaranteeing health as a right and to seek alignment with the recommendations from the WHO, which emphasizes recruitment strategies for human resources; implanting permanent education in rural health; conducting specific health research for this scenario, in addition to financing and organizing services in the rural context environment.

\section{REFERENCES}

1. Ministério da Saúde (BR). Portaria nº 2.436, de 21 de setembro de 2017. Aprova a Política Nacional de Atenção Básica, estabelecendo a revisão de diretrizes para a organização da Atenção Básica, no âmbito do Sistema Único de Saúde (SUS). Diário Oficial da União. 2017 set 22;154(183 Seção 1)68-76.

2. Dolea C, Stormont L, Braichet JM. Evaluated strategies to increase attraction and retention of health workers in remote and rural areas. Bull World Health Organ. 2010;88(5):379-85. doi: https://doi.org/10.2471/BLT.09.070607

3. Scopinho RA. Condições de vida e saúde do trabalhador em assentamento rural. Ciênc Saúde Coletiva. 2010;15(Suppl 1):1575-84. doi: https://doi.org/10.1590/ S1413-81232010000700069 
4. Zhu A, Tang S, Thi Hoai Thu N, Supheap L, Liu X. Analysis of strategies to attract and retain rural health workers in Cambodia, China, and Vietnam and context influencing their outcomes. Hum Resour Health. 2019;17(2):1-9. doi: https:// doi.org/10.1186/s12960-018-0340-6

5. Barreto BL. Health inequalities: a global perspective. Ciênc Saúde Coletiva. 2017;22(7):2097-2108. doi: https://doi.org/10.1590/1413-81232017227.027 42017

6. Instituto Brasileiro de Geografia e Estatística. Pesquisa Nacional de Saúde 2013: acesso e utilização dos serviços de saúde, acidentes e violências: Brasil, grande regiões e unidades da federação. Rio de Janeiro: IBGE, 2015 [cited 2019 Dec 26]. Available from: https://biblioteca.ibge.gov.br/visualizacao/livros/liv94074.pdf

7. Silva, JFS. Acesso das populações do campo, da floresta e das águas às ações e serviços no sistema único de saúde [tese]. Brasília, DF: Universidade de Brasília; 2017.

8. Pereira $L L$, Pacheco $L$. The challenges faced by the More Doctors Program in providing and ensuring comprehensive health care in rural areas in the Amazon region, Brazil. Interface (Botucatu). 2017;21(Suppl 1):1181-92. doi: https://doi. org/10.1590/1807-57622016.0383

9. Organização Pan-Americana da Saúde (US). Ampliação do papel dos enfermeiros na atenção primária à saúde. Washington, D.C.: OPAS; 2018 [cited 2019 Dec 10]. Available from: http://biblioteca.cofen.gov.br/wp-content/uploads/2018/05/ Ampliação-do-papel-dos-enfermeiros-na-atenção-primária-à-saúde.pdf

10. Moore GF, Audrey S, Barker M, Bond L, Bonell C, Hardeman W, et al. Process evaluation of complex interventions: Medical Research Council guidance. BMJ. 2015;350:h1258. doi: https://doi.org/10.1136/bmj.h1258

11. Silva EM, Portela RA, Medeiros ALF, Cavalcante MCW, Costa RTA. Os desafios no trabalho da enfermagem na estratégia saúde da família em área rural: revisão integrativa. Hygeia. 2018;14(28):1-12. doi: https://doi.org/10.14393/ Hygeia142801

12. Bardin L. Análise de conteúdo. São Paulo: Edições 70; 2016.

13. Instituto Brasileiro de Geografia e Estatística. Sinopse do Censo Demográfico 2010. Rio de Janeiro: IBGE; 2011 [cited 2020 Feb 15]. Available from: https:// biblioteca.ibge.gov.br/visualizacao/livros/liv49230.pdf
14. Fundo de População das Nações Unidas (BR). Mundos distantes: saúde e direitos reprodutivos em uma era de desigualdades: situação da população mundial em 2017. Brasilia, DF: UNFPA; 2017 [cited 2019 0ct 01]. Available from: http:// portaldeboaspraticas.iff.fiocruz.br/wp-content/uploads/2018/01/swop2017.pdf

15. Viegas APB, Carmo RF, Luz ZMP. Fatores que influenciam o acesso aos serviços de saúde na visão de profissionais e usuários de uma unidade básica de referência. Saúde Soc. 2015;24(1)100-12. doi: https://doi.org/10.1590/ S0104-12902015000100008

16. Oliveira AR, Sousa YG, Albuquerque IVA, Medeiros SM, Martiniano C, Alves M. The daily routine of nurses in rural areas in the Family Health Strategy. Rev Bras Enferm. 2019;72(4):918-95. doi: https://doi.org/10.1590/0034-7167-2018-0243

17. Ferreira SRS, Périco LAD, Dias VRGF. The complexity of the work of nurses in Primary Health Care. Rev Bras Enferm. 2018;71(1):784-9. doi: https://doi. org/10.1590/0034-7167-2017-0471

18. Peruzzo HE, Bega AG, Lopes APAT, Haddad MCFL, Peres AM, Marcon SS. Os desafios de se trabalhar em equipe na estratégia saúde da família. Esc Anna Nery. 2018;22(4):e20170372. doi: https://doi.org/10.1590/2177-9465-ean2017-0372

19. Santos RC, Miranda FAN. Importância do vínculo entre profissional-usuário na estratégia de saúde da família. Rev Enferm UFSM. 2016;6(3):350-9. doi: https://doi.org/10.5902/2179769217313

20. Ferreira EA, Alves DCSQ, Parnaíba FJB, Araújo RV, Vieira GP, Alencar AP, et al. Vínculo Profissional-Usuário na Estratégia FSG Saúde da Família: Percepções de Idosos Hipertensos. Id on Line Rev MultPsic. 2019 [cited 20190ct01];13(3):74860. Available from: https://idonline.emnuvens.com.br/id/article/viewFile/ $1561 / 2343$

\section{Acknowledgment:}

To the Foundation for Research Support of Minas Gerais (Fundação de Amparo à Pesquisa de Minas Gerais, FAPEMIG) for their financial support, to the CNPq for the productivity scholarship in research, and to CAPES for the DINTER UFMG/ UFCG scholarship.

\section{- Corresponding author:}

Arleusson Ricarte de Oliveira

E-mail: leussonricarte@gmail.com

\section{Associate editor:}

Rosana Maffacciolli 